\title{
PENGARUH PERSEPSI SISWA TENTANG KOMPETENSI \\ PROFESIONALISME GURU TERHADAP MOTIVASI BELAJAR DAN \\ PRESTASI BELAJAR MATA DIKLAT AKUNTANSI
}

\author{
Iftitahur Riddiniyah \\ Satuan Pengawasan Internal \\ Universitas Negeri Malang \\ IftitahurR_offE@yahoo.co.id
}

\begin{abstract}
This research examines the influences of student's perception about teachers' professional competence on motivation and achievement to learn accounting subject. This research includes quantitative research with explanatory method. The population in this research is all students of accounting special class in the public Vocational High School 1 Probolinggo in amount 312 students, and sample in this research is class XI students of accounting special class in amount 103 student. The variables in this research are student perception about teachers' professional competence $\left(\mathrm{X}_{1}\right)$, motivation to learn $\left(\mathrm{X}_{2}\right)$, and achievement to learn (Y). The data collection technique uses quetionaire and documentation. The analysis method uses path analysis. The result of research show that there is an indirect influence between student's perception about teachers' professional competence on achievement through motivation to learn with a contribution of 0.108 .
\end{abstract}

Keyword: Student's Perception About Teachers' Professional Competence, Motivation, Achievement.

Abstrak: Penelitian ini menguji pengaruh persepsi siswa tentang kompetensi profesionalisme guru terhadap motivasi belajar dan prestasi belajar mata dilat akuntansi. Penelitian ini termasuk penelitian kuantitatif dengan metode penjelas. Populasi dalam penelitian ini adalah seluruh siswa program keahlian akuntansi di SMK Negeri 1 Probolinggo yang berjumlah 312 siswa, dan sampel dalam penelitian ini adalah siswa kelas XI program keahlian akuntansi di SMK Negeri 1 Probolinggo yang berjumlah 103 siswa. Variabel dalam penelitian ini adalah persepsi siswa tentang kompetensi profesionalisme guru $\left(\mathrm{X}_{1}\right)$; motivasi belajar $\left(\mathrm{X}_{2}\right)$, dan prestasi belajar (Y). Teknik pengumpulan data menggunakan kuesioner dan dokumentasi. Metode analisis data menggunakan analisis jalur. Hasil penelitian menunjukkan bahwa terdapat pengaruh secara tidak langsung persepsi siswa tentang kompetensi profesionalisme guru terhadap prestasi belajar melalui motivasi belajar dengan kontribusi sebesar 0.108

Kata Kunci: Persepsi Siswa Tentang Kompetensi Profesionalisme Guru, Motivasi, Prestasi. 
Pendidikan merupakan investasi sumber daya manusia jangka panjang yang mempunyai nilai strategis bagi kelangsungan peradaban manusia di dunia. Keberhasilan pendidikan pada dasarnya tergantung pada banyak faktor, namun faktor terpenting di antara faktor-faktor tersebut adalah sumber daya pontensial guru yang mampu melakukan transformasi ilmu pengetahuan secara profesional kepada siswa. Perbaikan kualitas pendidikan pada prinsipnya berpangkal dari guru dan berujung pada guru pula. Guru profesional merupakan komponen paling menentukan dalam sistem pendidikan secara keseluruhan, yang harus mendapat perhatian sentral, pertama, dan utama, sehingga guru senantiasa menjadi sorotan strategis, karena guru selalu terkait dengan keseluruhan komponen dalam sistem pendidikan. Tanpa seorang guru profesional, pendidikan hanya akan menjadi slogan muluk karena segala bentuk kebijakan dan program pada akhirnya akan ditentukan oleh kinerja pihak yang berada di garis terdepan yaitu guru.

Dalam proses pendidikan, siswa pada dasarnya merupakan sentral yang harus dikembangkan potensinya. Guru menempati posisi yang sangat strategis dalam mengembangkan potensi siswa. Guru berperan membantu perkembangan siswa untuk dapat menerima dan memahami materi yang disampaikan oleh guru. Oleh karena itu, seorang guru dapat dikatakan profesional jika memiliki kemampuan memotivasi tinggi, sehingga menghasilkan proses dan hasil pendidikan yang berkualitas dalam rangka mewujudkan manusia Indonesia yang cerdas dan kompetitif, sebagaimana diamanatkan oleh UndangUndang Sistem Pendidikan Nasional.

Motivasi belajar kerap dikenal sebagai daya dorong untuk mencapai hasil yang baik, yang diwujudkan dalam bentuk tingkah laku belajar atau menunjukkan usaha-usaha untuk mencapai tujuan belajar. Menurut Usman (2010:28-29) motivasi merupakan suatu proses untuk menggiatkan motif-motif menjadi perbuatan atau tingkah laku untuk memenuhi kebutuhan dan mencapai tujuan, atau keadaan dan kesiapan dalam diri individu yang mendorong tingkah lakunya untuk berbuat sesuatu dalam mencapai tujuan tertentu.

Teori motivasi, yaitu Teori Harapan dan Teori Penguatan menyatakan bahwa motivasi belajar mempengaruhi prestasi belajar. Menurut Rahim (2008:80) prestasi belajar adalah hasil usaha siswa yang ditandai dengan adanya perubahan tingkah laku pada diri siswa. Perubahan tersebut mengakibatkan bertambahnya pengetahuan siswa. Sedangkan menurut Winkel dalam Rahim (2008:79) prestasi belajar diartikan sebagai perubahan-perubahan dalam bidang pengetahuan/pengalaman, keterampilan, nilai dan sikap.

Senada dengan teori motivasi, Sudjana dalam Mun'in (2009:5) menjelaskan bahwa motivasi belajar merupakan salah satu faktor intern yang mampu meningkatkan prestasi 
belajar. Motivasi memegang peranan yang signifikan bagi siswa dalam kegiatan belajar. Siswa yang kurang memiliki motivasi belajar akan sering merasa malas untuk melakukan aktivitas belajar sehingga tujuan yang dikehendaki akan sulit untuk tercapai. Sedangkan siswa yang memiliki motivasi belajar yang kuat akan lebih giat untuk melakukan aktivitas belajar, sehingga mudah mencapai prestasi yang diharapkan. Dimyati \& Mudjiono (2006:90) menjelaskan bahwa secara garis besar motivasi terbagi menjadi dua, yaitu: motivasi instrinsik, merupakan motif-motif yang menjadi aktif atau berfungsi dikarenakan orang tersebut senang melakukannya; dan motivasi ekstrinsik, merupakan motif-motif yang aktif dan berfungsi karena adanya dorongan terhadap perilaku seseorang yang ada di luar perbuatan yang dilakukannya.

Bagi siswa yang selalu memperhatikan materi pelajaran yang diberikan oleh guru, bukanlah masalah bagi guru karena di dalam diri siswa tersebut sudah tertanam motivasi intrinsik. Siswa yang demikian biasanya dengan kesadaran sendiri memperhatikan penjelasan guru, karena memiliki rasa ingin tahu lebih banyak terhadap materi pelajaran yang diberikan. Berbeda dengan siswa yang tidak tertanam motivasi intrinsik dalam dirinya, motivasi ekstrinsik yang merupakan dorongan dari luar diri siswa mutlak diperlukan. Di sinilah tugas guru yang profesional untuk dapat membangkitkan motivasi siswa sehingga siswa mau melakukan sesuatu atau belajar.

Guru sebagai salah satu instrumen pembelajaran mempunyai peranan yang besar dan strategis dalam proses pembelajaran, yaitu membangkitkan motivasi dalam diri siswa agar siswa semakin aktif dalam belajar. Oleh karena itu, guru harus mempunyai kompetensi profesional dalam melaksanakan tugas dan tanggungjawabnya. Kompetensi profesionalisme guru dapat diartikan sebagai kemampuan dan kewenangan guru dalam menjalankan profesi keguruannya. Artinya, guru yang tekun dalam melaksanakan profesinya dapat disebut guru yang kompeten dan profesional (Syah, 2010:229). Menurut Undang-Undang RI No.14 Tahun 2005 tentang Guru dan Dosen dinyatakan bahwa kompetensi guru meliputi kompetensi pedagogik, kompetensi kepribadian, kompetensi sosial, dan kompetensi profesional yang diperoleh melalui pendidikan profesi. Kompetensi pedagogik adalah kemampuan mengelola pembelajaran peserta didik. Kompetensi kepribadian adalah kemampuan kepribadian yang mantap, berakhlak mulia, arif, dan berwibawa serta menjadi teladan peserta didik. Kompetensi sosial adalah kemampuan guru untuk berkomunikasi dan berinteraksi secara efektif dan efisien dengan peserta didik, sesama guru, orangtua/wali peserta didik, dan masyarakat sekitar. Kompetensi profesional adalah kemampuan penguasaan materi pelajaran secara luas dan mendalam. Salah satu wujud kompetensi professional guru adalah pengajaran 
guru di kelas yang merupakan rangkaian pengalaman pertama yang dihadapi siswa. Siswa memaknai pengalaman ini melalui proses persepsi.

Menurut teori persepsi dinyatakan bahwa persepsi seseorang terhadap stimulus yang datang dapat mempengaruhi tingkah laku. Persepsi siswa adalah persepsi tentang kompetensi profesionalisme guru yang akan memberikan rangsangan/stimulus terhadap motivasi belajar siswa. Hasil persepsi mempengaruhi aktivitas mental selanjutnya, yaitu motivasi belajar siswa. Persepsi pada dasarnya merupakan suatu proses dengan mana individu-individu mengorganisasikan dan menafsirkan kesan indera mereka agar memberi makna kepada lingkungan mereka, Robbins (2001:88). Suprihanto, Harsiwi \& Hadi (2003:33) mendefinisikan persepsi sebagai suatu proses di mana individu memberi arti terhadap suatu fenomena yang terjadi berdasarkan kesan yang ditangkap oleh panca inderanya. Dengan perkataan lain, persepsi adalah suatu bentuk penilaian satu orang dalam menghadapi rangsangan yang sama, tetapi dalam kondisi lain akan menimbulkan persepsi yang berbeda.

Mengacu pada definisi tersebut, maka dapat dijelaskan bahwa stimulus yang diterima oleh siswa melalui inderanya adalah kompetensi profesionalisme guru yang kemudian diorganisasikan dan diinterpretasikan sehingga menimbulkan respon pada diri siswa. Respon yang ditimbulkan tergantung bagaimana siswa menyikapi stimulus yang diterima, apakah siswa akan menyikapi stimulus tersebut sebagai hal positif sehingga menimbulkan interpretasi yang positif dalam memaknai dan memberikan pengaruh yang positif pula dalam aktivitas mental siswa, atau sebaliknya menyikapi sebagai hal negatif sehingga menimbulkan interpretasi yang negatif dalam memaknai dan memberikan pengaruh yang negatif dalam aktivitas mental siswa.

Berdasarkan pandangan kognitivis, siswa yang tidak bereaksi terhadap rangsangan dari luar yang mengandung daya motivasional, tidak akan menunjukkan perubahan pada aktivitas mental siswa Sanjaya (2006:114). Dalam penelitian ini rangsangan dari luar yang dimaksud adalah persepsi positif siswa terhadap kompetensi profesionalisme guru. Apabila siswa memiliki persepsi positif terhadap kompetensi profesionalisme guru, maka akan meningkatkan motivasi belajar siswa yang pada akhirnya mampu meningkatkan prestasi belajar siswa. Dengan mengacu pada kerangka berpikir tersebut, diduga secara tidak langsung terdapat pengaruh positif persepsi siswa tentang kompetensi profesionalisme guru terhadap prestasi belajar melalui motivasi belajar.

Kerangka berpikir tersebut juga didukung oleh hasil studi empiris yang dilakukan oleh Diana (2010) yang menunjukkan bahwa terdapat pengaruh positif yang signifikan antar persepsi siswa tentang kompetensi kepribadian, kompetensi pedagogik, kompetensi 
profesional, dan kompetensi sosial terhadap motivasi belajar siswa baik secara parsial maupun simultan. Hasil penelitian Irawan (2010), Tyasari (2011), Firdaus (2012) juga menunjukkan adanya hubungan positif antara persepsi terhadap kompetensi guru dengan motivasi berprestasi pada siswa.

Berdasarkan paparan di atas, maka penelitian ini bermaksud menguji kembali pengaruh persepsi siswa tentang kompetensi profesionalisme guru terhadap motivasi belajar dan prestasi belajar.

\section{METODE}

Penelitian ini termasuk kuantitatif dengan metode eksplanasi (explanatory research). Penelitian eksplanasi bertujuan untuk menguji hubungan antar variabel yang dihipotesiskan (Sugiono, 2009:11). Variabel-variabel dalam penelitian ini adalah persepsi siswa tentang kompetensi profesionalisme guru (variabel bebas $/ \mathrm{X}_{1}$ ) terhadap motivasi belajar (variabel bebas sekaligus sebagai variabel intervening/ $\mathrm{X}_{2}$ ) dan prestasi belajar (variabel terikat/Y). Hubungan antara variabel tersebut digambarkan sebagai berikut.

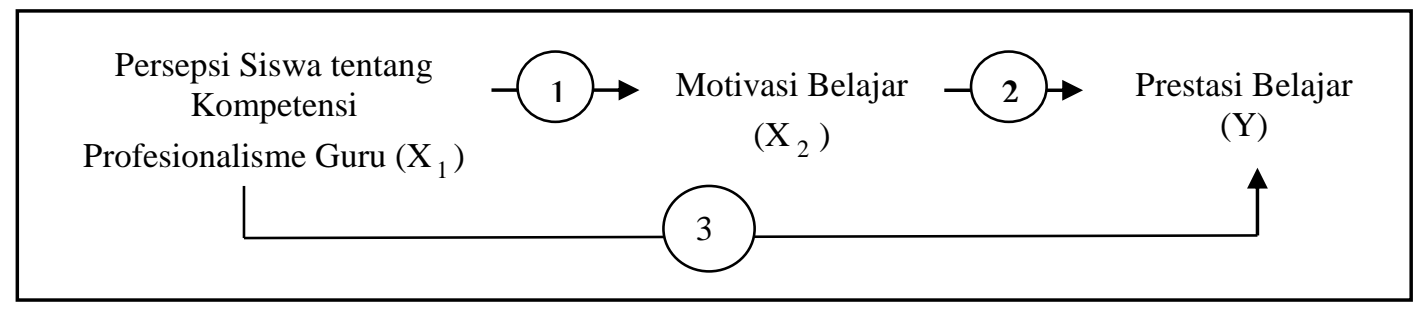

Gambar 1. Rancangan Penelitian

Populasi dalam penelitian ini adalah seluruh siswa program keahlian akuntansi di SMK Negeri 1 Probolinggo sejumlah 312 siswa. Sedangkan sampel dalam penelitian ini adalah siswa kelas XI program keahlian akuntansi di SMK Negeri 1 Probolinggo yang berjumlah 103 siswa.

Dalam penelitian ini, instrumen penelitian disusun dan dikembangkan dalam bentuk angket atau kuesioner. Pertanyaan-pertanyaan dirumuskan dalam kuesioner didasarkan pada indikator dengan maksud untuk memperoleh jawaban yang menghasilkan data kuantitatif untuk diolah secara statistik. Pengukuran variabel dalam penelitian ini berlandaskan pada skala likert. Artinya, dengan menggunakan skala likert, variabel yang akan diukur dijabarkan menjadi dimensi, dimensi dijabarkan lagi menjadi indikator yang terukur. Indikator yang 
terukur ini dapat dijadikan titik tolak untuk membuat instrumen yang berupa pertanyaan. Pilihan jawaban responden diberi bobot nilai antara 1-5. Pemberian skor terhadap alternatif jawaban kuesioner dijabarkan dalam tabel berikut.

Tabel 1. Jabaran Nilai Skala

\begin{tabular}{|c|c|}
\hline Jawaban Responden & Skor \\
\hline Sangat Setuju & 5 \\
\hline Setuju & 4 \\
\hline Netral & 3 \\
\hline Tidak Setuju & 2 \\
\hline Sangat Tidak Setuju & 1 \\
\hline
\end{tabular}

Sumber: Riduwan dan Kuncoro (2007:20-21)

Hasil uji validitas dan reabilitas instrumen adalah sebagai berikut.

Tabel 2. Hasil Uji Validitas Instrumen Variabel Persepsi Siswa tentang Kompetensi Profesionalisme Guru

\begin{tabular}{|c|c|c|c|}
\hline Item Pertanyaan & r hitung & Sig. & Ket. \\
\hline x1.01 & 0.550 & 0.000 & Valid \\
\hline x1.02 & 0.482 & 0.002 & Valid \\
\hline x1.03 & 0.681 & 0.000 & Valid \\
\hline x1.04 & 0.626 & 0.000 & Valid \\
\hline x1.05 & 0.735 & 0.000 & Valid \\
\hline x1.06 & 0.784 & 0.000 & Valid \\
\hline x1.07 & 0.539 & 0.000 & Valid \\
\hline x1.08 & 0.707 & 0.000 & Valid \\
\hline x1.09 & 0.626 & 0.000 & Valid \\
\hline x1.10 & 0.680 & 0.000 & Valid \\
\hline x1.11 & 0.754 & 0.001 & Valid \\
\hline x1.12 & 0.513 & 0.000 & Valid \\
\hline x1.13 & 0.610 & 0.000 & Valid \\
\hline x1.15 & 0.557 & 0.041 & \\
\hline
\end{tabular}

Sumber: Lampiran Hasil Uji Validitas Instrumen

Berdasarkan tabel 2 di atas dapat diketahui nilai $\mathrm{r}$ hitung untuk item pertanyaan1 hingga 15. Dengan nilai $\mathrm{r}$ tabel $\left(\mathrm{r}_{38(0.05)}\right)$ sebesar 0.320 sebagai pembanding, maka nilai $\mathrm{r}$ hitung untuk seluruh item pertanyaan lebih besar dari $r$ tabel ( $r$ hitung $>r$ tabel). Dengan demikian dapat disimpulkan bahwa item pertanyaan tersebut valid dan dapat digunakan dalam penelitian. 
Tabel 3. Hasil Uji Validitas Instrumen Variabel Motivasi Belajar

\begin{tabular}{|c|c|c|c|}
\hline Item Pertanyaan & r hitung & Sig. & Ket. \\
\hline x2.01 & 0.634 & 0.000 & Valid \\
\hline x2.02 & 0.485 & 0.002 & Valid \\
\hline x2.03 & 0.665 & 0.000 & Valid \\
\hline x2.04 & 0.613 & 0.000 & Valid \\
\hline x2.05 & 0.627 & 0.000 & Valid \\
\hline x2.06 & 0.653 & 0.000 & Valid \\
\hline x2.07 & 0.601 & 0.000 & Valid \\
\hline x2.08 & 0.815 & 0.000 & Valid \\
\hline x2.09 & 0.729 & 0.000 & Valid \\
\hline x2.10 & 0.761 & 0.000 & Valid \\
\hline x2.11 & 0.725 & 0.000 & Valid \\
\hline x2.12 & 0.598 & 0.000 & Valid \\
\hline x2.13 & 0.620 & 0.000 & Valid \\
\hline x2.14 & 0.653 & 0.000 & Valid \\
\hline x2.15 & 0.533 & 0.001 & Valid \\
\hline
\end{tabular}

Sumber: Lampiran Hasil Uji Validitas Instrumen

Berdasarkan tabel 3 di atas dapat diketahui nilai $r$ hitung untuk item pertanyaan1 hingga 15. Dengan nilai $\mathrm{r}$ tabel $\left(\mathrm{r}_{38(0.05)}\right)$ sebesar 0.320 sebagai pembanding, maka nilai $\mathrm{r}$ hitung untuk seluruh item pertanyaan lebih besar dari $r$ tabel ( $\mathrm{r}$ hitung $>\mathrm{r}$ tabel), Dengan demikian dapat disimpulkan bahwa item pertanyaan tersebut valid dan dapat digunakan dalam penelitian.

Tabel 4 Hasil Uji Reliabilitas Instrumen Variabel Persepsi Siswa tentang Kompetensi Profesionalisme Guru dan Variabel Motivasi Belajar

\begin{tabular}{|c|c|c|}
\hline Variabel Pertanyaan & Cronbach's Alpha & Keterangan \\
\hline Persepsi Siswa tentang Kompetensi Profesionalisme Guru $\left(\mathrm{X}_{1}\right)$ & 0.872 & Reliabel \\
\hline Motivasi Belajar $\left(\mathrm{X}_{2}\right)$ & 0.896 & Reliabel \\
\hline
\end{tabular}

Sumber: Lampiran Hasil Uji Reliabilitas Instrumen

Berdasarkan tabel 4 di atas dapat diketahui nilai Cronbach's Alpha pada variabel persepsi siswa tentang kompetensi profesionalisme guru sebesar 0.872 dan variabel motivasi belajar sebesar 0.896. Dengan menggunakan nilai kritis sebesar 0.600 sebagai pembanding, maka nilai Cronbach's Alpha lebih besar dari nilai kritis pembanding, sehingga dapat dikatakan bahwa variabel pertanyaan tersebut reliabel dan dapat digunakan dalam penelitian. 
Selain angket, data penelitian juga diperoleh dengan dokumentasi. Teknik dokumentasi ini digunakan untuk memperoleh data tentang prestasi belajar siswa.

Analisis data dalam penelitian ini menggunakan statistik inferensial parametrik, analisis jalur (path analysis). Analisis jalur pada dasarnya mempunyai kedekatan dengan analisis regresi linear berganda atau dengan kata lain analisis regresi linear berganda merupakan bentuk khusus dari analisis jalur Sunyoto (2011:1). Untuk mengetahui derajat hubungan antara variabel $\mathrm{X}_{1}$ terhadap $\mathrm{X}_{2}$ dan $\mathrm{Y}$ dilakukan dengan penyebaran kuesioner yang bersifat tertutup. Karena data dalam penelitian ini berskala rasio, maka statistik inferensial parametrik mensyaratkan untuk dipenuhinya beberapa asumsi klasik. Uji asumsi klasik dilakukan untuk mengetahui apakah model estimasi telah memenuhi kriteria ekonometrika, dalam arti tidak terjadi penyimpangan yang cukup serius dari asumsi-asumsi yang harus dipenuhi dalam metode Ordinary Least Square (OLS).

\section{HASIL PENELITIAN}

Hasil analisis menunjukkan bahwa persepsi siswa tentang kompetensi profesionalisme guru adalah tinggi (86\%); motivasi belajar siswa adalah tinggi ( $84 \%$ ); prestasi belajar siswa adalah baik (91\%).

Hasil uji normalitas data dengan Scatterplot Standardized Residual menunjukkan hasil bahwa titik-titik pada grafik menyebar di sekitar garis diagonal dan penyebaranya mengikuti arah garis diagonal. sehingga dikatakan data telah memenuhi asumsi normalitas dan layak dipakai pada model. Hasil uji normalitas data dengan uji kolmogrov-smirnov menunjukkan hasil bahwa variabel persepsi siswa tentang kompetensi profesionalisme guru $\left(\mathrm{x}_{1}\right)$, variabel motivasi belajar $\left(\mathrm{x}_{2}\right)$, variabel prestasi belajar $(\mathrm{y})$, galat model $1\left(\mathrm{e}_{1}\right)$, dan galat model $2\left(\mathrm{e}_{2}\right)$ memiliki nilai signifikansi yang lebih besar dari alpha 5\%. Artinya bahwa data penelitian berasal dari populasi yang berdistribusi normal, maka H0 diterima. Dengan demikian data penelitian dikatakan memenuhi asumsi normalitas dan layak dipakai pada model. Hasil uji linearitas data menunjukkan bahwa nilai signifikansi defiation from linearity untuk variabel persepsi siswa tentang kompetensi profesionalisme guru $\left(\mathrm{X}_{1}\right)$ sebesar 0.000 lebih kecil dari alpha 5\%. Artinya bahwa terdapat pengaruh linear variabel persepsi siswa tentang kompetensi profesionalisme guru terhadap variabel motivasi belajar; nilai signifikansi defiation from linearity untuk variabel persepsi siswa tentang kompetensi profesionalisme guru $\left(\mathrm{X}_{1}\right)$ sebesar 0.000 dan variabel motivasi belajar $\left(\mathrm{X}_{2}\right)$ sebesar 0.001 lebih kecil dari alpha 5\%. Artinya bahwa terdapat pengaruh linear variabel persepsi siswa tentang 
kompetensi profesionalisme guru dan variabel motivasi belajar terhadap variabel prestasi belajar, maka H1 diterima. Dengan demikian data penelitian dikatakan memenuhi asumsi linearitas dan layak dipakai pada model. Hasil uji non heterokedastisitas menunjukkan bahwa titik-titik pada grafik scatterplot non heterokedastisitas menyebar secara acak dan tidak membentuk pola tertentu, maka $\mathrm{H} 1$ diterima. Dengan demikian data penelitian dikatakan memenuhi asumsi non heterokedastisitas dan layak dipakai pada model.

Hasil pengujian hipotesis pertama dengan uji analisis regresi linear berganda ditunjukkan sebagai berikut.

Hipotesis pertama yang diajukan dalam penelitian ini berbunyi "terdapat pengaruh secara langsung persepsi siswa tentang kompetensi profesionalisme guru terhadap motivasi belajar siswa pada mata diklat produktif akuntansi kelas XI program keahlian akuntansi di SMK Negeri 1 Probolinggo".

Tabel 5. Hasil Uji Regresi Linear Berganda Model 1 Persepsi Siswa tentang Kompetensi Profesionalisme Guru terhadap Motivasi Belajar

\begin{tabular}{|l|c|c|c|}
\hline \multicolumn{1}{|c|}{ Variabel Bebas } & Standardized Coeficient Beta & t Hitung & Significant \\
\hline $\begin{array}{l}\text { Persepsi Siswa tentang Kompetensi } \\
\text { Profesionalisme Guru }\left(\mathrm{X}_{1}\right)\end{array}$ & 5.497 & 0.000 \\
\hline $\begin{array}{l}\text { Variabel Terikat : Motivasi Belajar } \\
\text { Konstanta } \quad: 31.915\end{array}$ & \\
$\mathrm{R}$ Square $\left(\mathrm{R}^{2}\right) \quad: 0.230$ & \\
$\left(\mathrm{e}_{1}\right) \quad: \sqrt{1-0.230^{2}}=0.973$ & & \\
\hline
\end{tabular}

Hasil uji analisis regresi linear berganda untuk hipotesis pertama menghasilkan persamaan berikut:

$$
x_{2}=a+b_{1} x_{1}+e_{1}=31.915+0.480 x_{1}+0.973
$$

Dari persamaan di atas diperoleh $\alpha=31.915$ dan $\beta_{1}=0.480$. Persamaan tersebut menunjukkan bahwa setiap kenaikan sebesar satu persepsi siswa tentang kompetensi profesionalisme guru, maka akan meningkatkan motivasi belajar sebesar 0.480. Saat persepsi siswa tentang kompetensi profesionalisme guru dianggap konstan atau bernilai nol, maka motivasi belajar adalah sebesar 31.915 .

Berdasarkan hasil pengujian pada tabel 5, terlihat nilai t hitung sebesar 5.497 lebih besar dari nilai t tabel sebesar 1.984 dan nilai signifikansi 0.000 lebih kecil dari nilai probabilitas 5\%. Hal ini berarti bahwa terdapat pengaruh secara langsung persepsi siswa tentang kompetensi profesionalisme guru terhadap motivasi belajar siswa. Hubungan positif 
atau searah ditunjukkan dengan nilai positif pada standardized coeficient beta sebesar 0.480 , maka $\mathrm{Ha}_{1}$ diterima. Artinya bahwa semakin meningkatnya persepsi siswa tentang kompetensi profesionalisme guru maka semakin meningkat pula motivasi belajar siswa. Besarnya koefisien determinasi $\left(\mathrm{R}^{2}\right)$ adalah 0.230 menunjukkan kontribusi variabel persepsi siswa tentang kompetensi profesionalisme guru sebesar 23.0\%. Jadi dapat disimpulkan bahwa persepsi siswa tentang kompetensi profesionalisme guru berpengaruh secara langsung terhadap motivasi belajar siswa pada mata diklat produktif akuntansi kelas XI program keahlian akuntansi di SMK Negeri 1 Probolinggo.

Hasil pengujian hipotesis kedua dengan uji analisis regresi linear berganda ditunjukkan sebagai berikut.

Hipotesis kedua yang diajukan dalam penelitian ini berbunyi "terdapat pengaruh secara langsung motivasi belajar siswa terhadap prestasi belajar siswa pada mata diklat produktif akuntansi kelas XI program keahlian akuntansi di SMK Negeri 1 Probolinggo".

Tabel 6. Hasil Uji Regresi Linear Berganda Model 2 Persepsi Siswa tentang Kompetensi Profesionalisme Guru dan Motivasi Belajar terhadap Prestasi Belajar

\begin{tabular}{|c|c|c|c|}
\hline Variabel Bebas & Standardized Coeficien Beta & $\mathbf{t}_{\text {Hitung }}$ & Significant \\
\hline $\begin{array}{l}\text { Persepsi Siswa tentang Kompetensi } \\
\text { Profesionalisme Guru }\left(\mathrm{X}_{1}\right)\end{array}$ & 0.229 & 2.186 & 0.031 \\
\hline Motivasi Belajar $\left(\mathrm{X}_{2}\right)$ & 0.224 & 2.136 & 0.035 \\
\hline 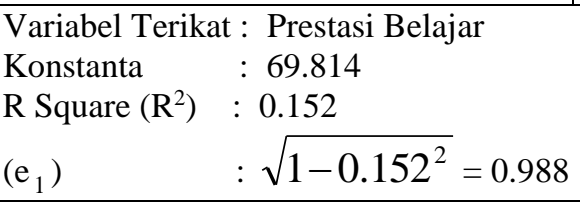 & & & \\
\hline
\end{tabular}

Hasil uji analisis regresi linear berganda untuk hipotesis kedua menghasilkan persamaan berikut :

$$
y=a+b_{1} x_{1}+b_{2} x_{2}+e_{2}=69.814+0.229 x_{1}+0.224 x_{2}+0.988
$$

Dari persamaan di atas diperoleh $\alpha=69.814, \beta_{1}=0.229, \beta_{2}=0.224$. Persamaan tersebut menunjukkan bahwa setiap kenaikan sebesar satu persepsi siswa tentang kompetensi profesionalisme guru dengan asumsi motivasi belajar tetap, maka akan meningkatkan prestasi belajar sebesar 0.229. Setiap kenaikan sebesar satu motivasi belajar dengan asumsi persepsi siswa tentang kompetensi profesionalisme guru tetap, maka akan meningkatkan prestasi belajar sebesar 0.224. Saat persepsi siswa tentang kompetensi profesionalisme guru dan 
motivasi belajar dianggap konstan atau bernilai nol, maka prestasi belajar adalah sebesar 69.814.

Berdasarkan hasil pengujian pada tabel 6 di atas, terlihat nilai t hitung sebesar 2.136 lebih besar dari nilai t tabel sebesar 1.984 dan nilai signifikansi 0.035 lebih kecil dari nilai probabilitas 5\%. Hal ini berarti bahwa terdapat pengaruh secara langsung motivasi belajar siswa terhadap prestasi belajar siswa. Hubungan positif atau searah ditunjukkan dengan nilai positif pada standardized coeficient beta sebesar 0.224 , maka $\mathrm{Ha}_{2}$ diterima. Artinya bahwa semakin meningkatnya motivasi belajar siswa maka semakin meningkat pula prestasi belajar siswa. Besarnya koefisien determinasi $\left(\mathrm{R}^{2}\right)$ adalah 0.152 menunjukkan kontribusi variabel persepsi siswa tentang kompetensi profesionalisme guru dan variabel motivasi belajar sebesar 15.2\%. Jadi dapat disimpulkan bahwa terdapat pengaruh secara langsung motivasi belajar siswa terhadap prestasi belajar siswa pada mata diklat produktif akuntansi kelas XI program keahlian akuntansi di SMK Negeri 1 Probolinggo.

Hasil pengujian hipotesis ketiga dengan anlisis jalur (path analysis) ditunjukkan sebagai berikut.

Pengaruh tidak langsung variabel persepsi siswa tentang kompetensi profesionalisme guru $\left(\mathrm{x}_{1}\right)$ terhadap variabel prestasi belajar $(\mathrm{y})$ melalui variabel motivasi belajar $\left(\mathrm{x}_{2}\right)$ diperoleh dari hasil perkalian standardized coeficient beta $\left(\mathrm{x}_{1}-\mathrm{x}_{2}\right)$ dengan standardized coeficient beta $\left(\mathrm{x}_{2}-\mathrm{y}\right)$, yaitu: 0.480 x $0.224=0.108$, maka $\mathrm{Ha}_{3}$ diterima. Sedangkan besarnya pengaruh total diperoleh dari penjumlahan pengaruh langsung $\left(\mathrm{x}_{1}-\mathrm{y}\right)$ dan pengaruh tidak langsung $\left(\mathrm{x}_{1}-\mathrm{y}\right.$ melalui $\left.\mathrm{x}_{2}\right)$, yaitu: $0.229+0.108=0.337$.

Dengan demikian dapat disimpulkan bahwa terdapat pengaruh secara tidak langsung persepsi siswa tentang kompetensi profesionalisme guru terhadap prestasi belajar siswa melalui motivasi belajar siswa pada mata diklat produktif akuntansi kelas XI program keahlian akuntansi di SMK Negeri 1 Probolinggo.

\section{PEMBAHASAN}

Terdapat pengaruh secara langsung persepsi siswa tentang kompetensi profesionalisme guru terhadap motivasi belajar siswa pada mata diklat produktif akuntansi kelas XI program keahlian akuntansi di SMK Negeri 1 Probolinggo. Hasil uji statistik deskriptif penelitian menunjukkan bahwa $86 \%$ siswa memiliki persepsi yang tinggi terhadap kompetensi profesionalisme guru dan $84 \%$ siswa memiliki motivasi belajar yang tinggi. Hal ini menunjukkan bahwa kedua variabel tersebut berada pada kategori yang sejalan. Artinya, 
apabila persepsi siswa tentang kompetensi profesionalisme guru tinggi maka motivasi belajar siswa akan cenderung tinggi pula. Hasil pengujian hipotesis menunjukkan bahwa nilai t hitung sebesar 5.497 lebih besar dari nilai t tabel sebesar 1.984 dan nilai signifikansi 0.000 lebih kecil dari nilai probabilitas 5\%. Hal ini berarti bahwa terdapat pengaruh secara langsung persepsi siswa tentang kompetensi profesionalisme guru terhadap motivasi belajar siswa. Hubungan positif atau searah ditunjukkan dengan nilai positif pada standardized coeficient beta sebesar 0.480 , menyatakan bahwa semakin meningkatnya persepsi siswa tentang kompetensi profesionalisme guru maka semakin meningkat pula motivasi belajar siswa. Berdasarkan persamaan yang dihasilkan dari pengujian hipotesis pertama dengan regresi linear berganda menunjukkan bahwa setiap kenaikan sebesar satu persepsi siswa tentang kompetensi profesionalisme guru, maka akan meningkatkan motivasi belajar sebesar 0.480. Saat persepsi siswa tentang kompetensi profesionalisme guru dianggap konstan atau bernilai nol, maka motivasi belajar adalah sebesar 31.915. Hasil penelitian ini sesuai dengan teori yang pada dasarnya menjadi acuan dalam pengembangan hipotesis penelitian yang menyatakan bahwa persepsi siswa terhadap stimulus yang datang dapat mempengaruhi tingkah lakunya (Ivancevich, Konopaske \& Matteson, 2007:117), (Luthans, 2006:197-198), (Robbins, 2001:88), (Suprihanto, Harsiwi \& Hadi, 2003:33), (Thoha, 2009:148-149). Stimulus yang dimaksud adalah sosok guru dengan kompetensi profesionalisme yang dimilikinya yang menghendaki adanya respon dari siswa berupa motivasi belajar. Hasil penelitian ini juga sesuai dengan fakta empiris yang dikemukakan oleh Tyasari (2011) yang menunjukkan bahwa terdapat pengaruh positif yang signifikan antara persepsi siswa tentang kompetensi kepribadian, kompetensi pedagogik, kompetensi profesional dan kompetensi sosial terhadap motivasi belajar mahasiswa baik secara parsial maupun simultan, dan Diana (2010) yang menunjukkan bahwa terdapat pengaruh positif yang signifikan antara persepsi siswa tentang kompetensi kepribadian, kompetensi pedagogik, kompetensi profesional dan kompetensi sosial terhadap motivasi belajar siswa baik secara parsial maupun simultan. Guru adalah salah satu instrumental input yang mempunyai peranan besar dan strategis dalam proses pembelajaran. Sebagai pengajar dan pendidik, guru merupakan salah satu faktor penentu keberhasilan setiap upaya pendidikan, khususnya dalam kurikulum dan penngkatan sumber daya manusia yang dihasilkan dari upaya pendidikan selalu bermuara pada faktor guru. Hal ini menunjukkan betapa eksisnya peran guru dalam dunia pendidikan. Demikian pula dalam upaya membelajarkan siswa, guru dituntut memiliki multi peran sehingga mampu menciptakan kondisi belajar mengajar yang efektif. Agar dapat mengajar efektif, guru harus meningkatkan kesempatan belajar bagi siswa (kuantitas) dan meningkatkan mutu (kualitas) 
mengajarnya. Kesempatan belajar siswa dapat ditingkatkan dengan cara melibatkan siswa secara aktif dalam belajar. Memulai dan mengakhiri belajar tepat pada waktunya. Hal ini berarti kesempatan belajar makin banyak dan optimal serta guru menunjukkan keseriusan mengajar sehingga dapat membangkitkan minat dan motivasi belajar. Sedangkan dalam meningkatkan kualitas dalam mengajar, guru hendaknya mampu merencanakan program pengajaran dan sekaligus mampu pula melakukannya dalam bentuk interaksi belajar mengajar. Pada dasarnya, jalan pengajaran yang kondusif adalah kondisi belajar mengajar yang menyenangkan bagi siswa. Kegairahan belajar siswa terkuak sebagai implementasi dari umpan motivasinya. Siswa giat belajar, tidak ada yang diam, sesuai dengan harapan guru. Apa yang guru perinytahkan tidak mendapat bantahan dari siswa, namun mereka menuntut aturan pegajaran yang dibuat oleh guru. Siswa belajar dengan konsentrasi tanpa mendapatkan gangguan yang berarti dari lingkungan sekitarnya. Guru yang hanya mengajar dan tanpa memperhatikan mengerti tidaknya siswa terhadap bahan pelajaran yang disampaikan, akan mendapatkan reaksi negatif dari siswa. Siswa merasa kurang senang terhadap pengajaran guru. Sehingga menimbulkan persepsi siswa yang rendah terhadap kompetensi profesionalisme guru. Sedangkan guru yang menyadari kelemahan dirinya untuk menjelaskan isi dari bahan pelajaran yang disampaikan kemudian memanfaatkan alat bantu untuk membantu memperjelas isi dari bahan pelajaran, maka dapat dikatakan bahwa guru sangat memperhatikan kemampuan siswa. Dengan demikian akan menimbulkan persepsi siswa yang tingggi terhadap kompetensi profesionalisme guru. Salah satu fakta yang menunjukkan gambaran tingkat profesionalisme guru adalah dapat dilihat diri penyusunan Rencana Pelaksanaan Pembelajaran sekaligus implementasinya. Di SMK Negeri 1 Probolinggo, kompetensi profesionalisme guru mata diklat produktif akuntansi dapat dikatakan tinggi dilihat dari segi penyusunan Rencana Pelakasanaan Pembelajaran sekaligus penerapannya. Dikatakan demikian karena guru telah mampu membangkitkan motivasi belajar siswa melalui penggunaan media pembelajaran yang menarik, penerapan berbagai macam strategi pembelajaran, memanfaatkan waktu pembelajaran dengan baik, dan lain sebagainya. Pengajaran guru di kelas tersebut pada dasarnya merupakan rangkaian pengalaman pertama yang dihadapi siswa. Siswa memaknai pengalaman ini melalui proses persepsi dan hasil persepsi mempengaruhi aktivitas mental selanjutnya. Salah satu aktivitas mental yang terpengaruh adalah motivasi belajar siswa.

Terdapat pengaruh secara langsung motivasi belajar siswa terhadap prestasi belajar siswa pada mata diklat produktif akuntansi kelas XI program keahlian akuntansi di SMK Negeri 1 Probolinggo. Hasil uji statistik deskriptif penelitian menunjukkan bahwa $84 \%$ siswa 
memiliki motivasi belajar yang tinggi dan $91 \%$ siswa memiliki prestasi belajar yang baik. Hal ini menunjukkan bahwa kedua variabel tersebut berada pada kategori yang sejalan. Artinya, apabila motivasi belajar siswa tinggi maka prestasi belajar siswa akan cenderung baik. Hasil pengujian hipotesis menunjukkan bahwa nilai t hitung sebesar 2.136 lebih besar dari nilai $\mathrm{t}$ tabel sebesar 1.984 dan nilai signifikansi 0.035 lebih kecil dari nilai probabilitas $5 \%$. Hal ini berarti bahwa terdapat pengaruh secara langsung motivasi belajar siswa terhadap prestasi belajar siswa. Hubungan positif atau searah ditunjukkan dengan nilai positif pada standardized coeficient beta sebesar 0.224 , menyatakan bahwa semakin meningkatnya motivasi belajar siswa maka semakin meningkat pula prestasi belajar siswa. Berdasarkan persamaan yang dihasilkan dari pengujian hipotesis kedua dengan regresi linear berganda menunjukkan bahwa setiap kenaikan sebesar satu persepsi siswa tentang kompetensi profesionalisme guru dengan asumsi motivasi belajar tetap, maka akan meningkatkan prestasi belajar sebesar 0.229. Setiap kenaikan sebesar satu motivasi belajar dengan asumsi persepsi siswa tentang kompetensi profesionalisme guru tetap, maka akan meningkatkan prestasi belajar sebesar 0.224. Saat persepsi siswa tentang kompetensi profesionalisme guru dan motivasi belajar dianggap konstan atau bernilai nol, maka prestasi belajar adalah sebesar 69.814. Hasil penelitian ini sesuai dengan teori motivasi Teori Harapan; Victor Vroom, yang menyatakan bahwa prestasi adalah fungsi perkalian antara motivasi dengan ability, dan Teori Penguatan; B.F Skinner, mengemukakan bahwa keperilakuan dari suatu perangsang/stimulus akan menghasilkan tanggapan. Tanggapan yang mengarah pada prestasi yang baik perlu dipertahankan dan/atau ditingkatkan, yaitu dengan jalan memberikan penguatan. Kedua teori tersebut menunjukkan bahwa tinggi rendahnya prestasi yang dicapai tergantung pada tinggi rendahnya motivasi (Suprihanto, 2003:42-53). Hasil penelitian ini juga senada dengan pendapat Callahan and Clark dalam Mulyasa (2009:58), Dimyati dan Mudjiono (2006:80), Hamalik (2008:158), Luthans (2006:270), Mulyasa (2009:58), Munadi (2008:29), Usman (2010:28-29) dan Yamin (2010:80) yang menyatakan bahwa motivasi dapat berfungsi sebagai daya penggerak/pendorong pencapaian prestasi. Artinya bahwa siswa yang memiliki motivasi kuat dalam belajar akan memiliki banyak energi untuk melakukan kegiatan belajar sehingga akan memudahkan siswa mencapai prestasi belajar yang pada dasarnya menjadi tujuan belajar. Makin banyak siswa yang terlibat aktif dalam belajar, makin tinggi kemungkinan prestasi belajar yang dicapai oleh siswa. Motivasi belajar pada dasarnya merupakan faktor psikis yang bersifat non-intelektual. Hal ini karena peranannya yang khas dalam hal menumbukan, mendorong, serta mengarahkan gairah, minat dan semangat untuk belajar. Siswa yang memiliki motivasi belajar kuat, akan mempunyai banyak energi untuk 
melakukan kegiatan belajar. Motivasi juga merupakan salah satu faktor yang dapat meningkatkan kualitas pembelajaran, karena peserta didik akan belajar dengan sungguhsungguh apabila memiliki motivasi yang tinggi. Sering dijumpai siswa yang memiliki intelegensi yang tinggi tetapi prestasi belajar yang dicapainya rendah, akibat kemampuan intelektual yang dimilikinya tidak/kurang berfungsi secara optimal. Salah satu faktor pendukung agar kemampuan intelektual yang dimiliki siswa dapat berfungsi secara optimal adalah adanya motivasi untuk yang tinggi dalam dirinya. Motivasi merupakan perubahan tenaga di dalam diri seseorang yang ditandai oleh dorongan afektif dan reaksi-reaksi untuk mencapai tujuan belajar. Motivasi dimulai dengan suatu perubahan tenaga dalam diri seseorang dan ditandai oleh dorongan afektif yang kadang tampak dan kadang sulit diamati dan juga ditandai oleh reaksi-reaksi untuk mencapai tujuan. Siswa akan berusaha sekuat tenaga apabila dia memiliki motivasi yang besar untuk mencapai tujuan belajar. Siswa akan belajar dengan sungguh-sungguh tanpa dipaksa, bila memiliki motivasi yang besar; yang dengan demikian diharapkan akan mencapai prestasi yang tinggi. Adanya motivasi yang tinggi dalam diri siswa merupakan syarat agar siswa terdorong oleh kemauannya sendiri untuk mengatasi berbagai kesulitan belajar yang dihadapinya, dan lebih lanjut siswa akan sanggup untuk belajar sendiri.

Terdapat pengaruh secara tidak langsung persepsi siswa tentang kompetensi profesionalisme guru terhadap prestasi belajar siswa melalui motivasi belajar siswa pada mata diklat produktif akuntansi kelas XI program keahlian akuntansi di SMK Negeri 1 Probolinggo. Hasil uji statistik deskriptif penelitian menunjukkan bahwa $86 \%$ siswa memiliki persepsi yang tinggi terhadap kompetensi profesionalisme guru, $84 \%$ siswa memiliki motivasi belajar yang tinggi dan $91 \%$ siswa memiliki prestasi belajar yang baik. Hal ini menunjukkan bahwa ketiga variabel tersebut berada pada kategori yang sejalan. Artinya, apabila persepsi siswa tentang kompetensi profesionalisme guru tinggi, maka motivasi belajar siswa akan tinggi pula, dan secara tidak langsung menyebabkan prestasi belajar yang dicapai oleh siswa cenderung baik. Hasil analisis data dengan analisis jalur (path analysis) menunjukkan adanya pengaruh tidak langsung variabel persepsi siswa tentang kompetensi profesionalisme guru terhadap variabel prestasi belajar siswa melalui variabel motivasi belajar siswa sebesar 0.108 dengan pengaruh total sebesar $0.480+0.108=0.588$. Hasil penelitian ini sesuai dengan teori pandangan kognitivis yang menonjolkan peranan dari keyakinan, tujuan, penafsiran, harapan, minat, kemampuan dan lain sebagainya yang terdapat dalam diri siswa (Sanjaya, 2006:114). Pandangan ini menggarisbawahi apa yang berlangsung dalam diri siswa saat berhadapan dengan berbagai kejadian dan pengalaman. Jadi menurut 
pandangan ini siswa tidak bereaksi terhadap rangsangan dari luar atau dari dalam yang mengandung daya motivasional. Proses belajar mengajar di sekolah bersifat sangat kompleks, karena di dalamnya terdapat aspek pedagogis, psikologis, dan didaktis. Aspek pedagogis merujuk pada kenyataan bahwa belajar mengajar di sekolah terutama di sekolah dasar berlangsung dalam lingkungan pendidikan dimana guru harus mendampingi siswa dalam perkembangannya menuju kedewasaan, melalui proses belajar mengajar di dalam kelas. Aspek psikologis merujuk pada kenyataan bahwa siswa yang belajar di sekolah memiliki kondisi fisik dan psikologis yang berbeda-beda. Selain itu, aspek psikologis merujuk pada kenyataan bahwa proses belajar itu sendiri sangat bervariasi, misalnya: ada belajar materi yang mengandung aspek hafalan, ada belajar keterampilan motorik, ada belajar konsep, ada belajar sikap dan seterusnya. Adanya kemajemukan ini menyebabkan cara siswa belajar harus berbeda-beda pula, sesuai dengan jenis belajar yang sedang berlangsung. Aspek didaktis merujuk pada. pengaturan belajar siswa oleh tenaga. pengajar. Dalam hal ini guru harus menentukan metode yang paling efektif untuk proses belajar mengajar tertentu sesuai dengan tujuan instruksional yang harus dicapai. Dilihat dari sisi ini, terlihat bahwa betapa pentingnya kedudukan guru dalam membangkitkan motivasi belajar siswa dengan tujuan untuk meningkatkan prestasi belajar siswa. Prestasi siswa dipengaruhi oleh banyak faktor, namun yang paling menentukan adalah faktor guru. Dalam hal ini guru sangat berperan dalam menentukan cara yang dianggap efektif untuk membelajarkan siswa, baik di sekolah maupun di luar jam sekolah, misalnya dengan memberikan pekerjaan rumah. Ketidakpedulian guru terhadap pembelajaran siswa akan membawa kernerosotan bagi perkembangan siswa. Guru yang sering memberikan latihan-latihan dalam rangka pemahaman materi akan menghasilkan siswa yang lebih baik bila dibandingkan dengan guru yang hanya sekedar menjelaskan dan tidak memberi tindak lanjut secara kontinu. Dengan kata lain, prestasi belajar siswa sangat ditentukan oleh cara mengajar guru yang akan menciptakan kebiasaan belajar pada. siswa (meningkatkan motivasi belajar siswa). Sejalan dengan pandangan tersebut, orang terutama dilihat sebagai sumber motivasinya sendiri berdasarkan kegiatan mental dalam alam pikirannya, sehingga tergerak untuk memulai aktivitas tertentu, bertahan dalam aktivitas tersebut dan mengarahkannya untuk mencapai suatu tujuan. Rangsangan terkait dengan penelitian ini adalah kompetensi profesionalisme guru, sedangkan interpretasinya adalah persepsi siswa tentang kompetensi profesionalisme guru. Persepsi siswa tentang kompetensi profesionalisme guru ini merupakan rangsangan bagi motivasi belajar siswa, sehingga siswa tergerak untuk melakukan aktivitas belajar dalam rangka mencapai suatu tujuan belajar yaitu prestasi belajar yang baik. Artinya, apabila persepsi siswa tentang kompetensi 
profesionalisme guru tinggi maka akan diikuti dengan motivasi belajar yang tinggi pula, sehingga secara tidak langsung akan meningkatkan prestasi belajar siswa.

\section{SIMPULAN DAN SARAN}

Berdasarkan hasil penelitian dan pembahasan yang telah diuraikan, dapat ditarik kesimpulan bahwa: terdapat pengaruh secara langsung persepsi siswa tentang kompetensi profesionalisme guru terhadap motivasi belajar siswa pada mata diklat produktif akuntansi kelas XI program keahlian akuntansi di SMK Negeri 1 Probolinggo; terdapat pengaruh secara langsung motivasi belajar siswa terhadap prestasi belajar siswa pada mata diklat produktif akuntansi kelas XI program keahlian akuntansi di SMK Negeri 1 Probolinggo; terdapat pengaruh secara tidak langsung persepsi siswa tentang kompetensi profesionalisme guru terhadap prestasi belajar siswa melalui motivasi belajar siswa pada mata diklat produktif akuntansi kelas XI program keahlian akuntansi di SMK Negeri 1 Probolinggo.

Saran yang dapat diberikan terkait penelitian ini adalah: (1) Bagi para guru mata diklat produktif akuntansi sebaiknya berusaha untuk terus meningkatkan kompetensi profesionalismenya dengan melanjutkan pendidikan ke jenjang yang lebih tinggi dan mengikuti seminar atau penelitian yang dapat mengembangkan kompetensinya serta memperluas ilmu di bidang yang digelutinya; (2) Pimpinan lembaga, Kepala Sekolah SMK Negeri 1 Probolinggo sebaiknya sering memberikan pelatihan atau seminar yang dapat meningkatkan kompetensi profesionalisme guru SMK Negeri 1 Probolinggo; (3) Para siswa SMK Negeri 1 Probolinggo sebaiknya mampu menjadikan persepsinya tentang kompetensi profesionalisme guru sebagai sarana untuk meningkatkan motivasi belajarnya, sehingga siswa dengan mudah mencapai prestasi belajar yang baik. (4) Pembaca yang berminat meneliti kasus sejenis untuk menggunakan populasi dengan lingkup yang lebih luas serta mengembangkan permasalahan terkait dengan penelitian ini dengan cara menambah variabel yang belum dibahas dalam penelitian ini.

\section{Daftar Pustaka}

Dimyati \& Mudjiono.2006.Belajar dan Pembelajaran.Jakarta:Rineka Cipta.

Hamalik, Oemar.2008.Proses Belajar Mengajar.Jakarta:Bumi Aksara.

Irawan, Pangky.2010.Hubungan Persepsi terhadap Kompetensi Guru dengan Motivasi Berprestasi Siswa Kelas VII SMP Negeri 2 Tirto.Jurnal Ilmu Pendidikan, (online), (http://pdfsb.com/readonline/596c42426567743158334631446e526b55513d3d557758), diakses 1 januari 2012. 
Ivancevich, dkk.2007.Perilaku dan Manajemen Organisasi.Jakarta:Erlangga.

Luthans, Fred.2006.Perilaku Organisasi.Yogyakarta:ANDI.

Sardiman.A.2011..Interaksi dan Motivasi Belajar Mengajar.Jakarta:Raja Grafindo Persada.

Mulyasa, E.2009.Standar Kompetensi dan Sertifikasi Guru.Bandung:Remaja Rosdakarya.

Munadi, Yudhi.2008.Media Pembelajaran (Sebuah Pendekatan Baru).Jakarta: Gaung Persada.

Rahim, Utu.2010. Meningkatkan Prestasi Belajar Matematika Siswa Pada Pokok Bahasan Faktorisasi Suku Aljabar Melalui Pendekatan Struktural Think Pair Share (TPS) Siswa Kelas VII SMPN 4 Kendari.Jurnal Ilmu Pendidikan, (Online), 9 (1) : 78-86, (http://www.google.co.id/url?sa=t\&rct=j\&q=jurnal\%20prestasi\%20belajar\%20\%28pd f\%29\&source=web\&cd=4\&ved=0CDMQFjAD\&url=http\%3A\%2F\%2Fjurnal.unhalu. ac.id\%2Fdownload\%2Futurahim\%2FMENINGKATKAN\%2520PRESTASI\%2520BELAJAR\%2520MATEMA TIKA\%2520SISWA\%2520PADA.pdf\&ei=7V2PT6eFIMryrQfNt7mZBQ\&usg=AFQj CNHJx81BT0bcH6-r-pSpYu_5uarxYg\&cad=rja), diakses 1 januari 2012.

Riduwan \& Kuncoro, E.A.2007.Cara Menggunakan dan Memakai Analisis Jalur (Path Analysis).Bandung:Alfabeta.

R., Ahmad Mun'im.2009.Hubungan Prestasi Belajar Program Diklat Kewirausahaan dengan Minat Berwiraswasta Siswa Kelas III SMK Negeri 1 Samarinda.Jurnal Ilmu

Pendidikan. (http://guruvalah.20m.com/minat_berwiraswasta.pdf), diakses 1 januari 2012.

Robbins, S.P.2001 Perilaku Organisasi.Jakarta:Prenhallindo.

Sanjaya, Wina. 2006.Strategi Pembelajaran (Berorientasi Standar Proses Pendidikan). Jakarta:Kencana Prenada Media Group.

Sunyoto, Danang.2011.Riset Bisnis dengan Analisis Jalur SPSS. Yogyakarta:Gava Media.

Suprihanto, J., Harsiwi, TH.A.M., Hadi, P.2003.Perilaku Organisasi.Yogyakarta: STIEYKPN.

Syah, Muhibbin.2010.Psikologi Pendidikan dengan Pendekatan Baru.Bandung: Remaja Rosdakarya.

Thoha, Miftah.2009.Perilaku Organisasi (Konsep Dasar dan Aplikasinya). Jakarta:Raja Grafindo Persada.

Undang-Undang Republik Indonesia No. 14 Tahun 2005 tentang Guru dan Dosen.2006. Bandung:Citra Umbara.

Usman, Uzer.2010.Menjadi Guru Profesional.Bandung:Remaja Rosdakarya

Yamin, Martinis.2010.Strategi Pembelajaran Berbasis Kompetensi.Jakarta:Gaung Persada. 